\title{
Diversity in New Zealand Gnaphalieae
}

\author{
Ilse Breitwieser ${ }^{1} \mathbb{D}$ \& Josephine M.Ward ${ }^{2}$ \\ ' Allan Herbarium - Landcare Research, P.O. Box 69040, Lincoln 7640, New Zealand; breitwieseri@landcareresearch.co.nz \\ 2 School of Biological Sciences, University of Canterbury, Private Bag 4800, Christchurch 8I 40, New Zealand; josephine.ward@canterbury.ac.nz
}

DOI: http://dx.doi.org/l 0.53875/capitulum.01.2.02

\begin{abstract}
New Zealand indigenous Gnaphalieae are examined for endemism, ecological and morphological diversity, hybridism and taxonomic difficulty. The Raoulia alliance, an almost endemic clade, is shown to be remarkably diverse in morphology but with some interconnections within this diversity. Similarities between Leucogenes and Leontopodium, Anaphalioides and Anaphalis, Raoulia and Mniodes, and Ewartiothamnus and Ewartia are hypothesized to be due to the independent acquisition of remarkably similar morphological adaptations.
\end{abstract}

Keywords: convergent evolution, endemism, hybridism, morphology, Raoulia alliance

\section{OVERVIEW}

Compositae/Asteraceae tribe Gnaphalieae Cass. ex Lecoq \& Juill. comprises about 2, 100 species in 178 genera (Smissen et al., 2020), of which 65 species in I I genera are indigenous to New Zealand (Schönberger et al., 2020). Only species that have been formally described are included in this number and in the following account. Many species await description, particularly in Craspedia G.Forst. and Raoulia Hook.f. The New Zealand Gnaphalieae flora is noteworthy for its degree of endemism, ecological and morphological diversity, propensity for hybridization and taxonomic intractability.

The New Zealand seed plant flora as a whole has a remarkable degree of endemism, with $82 \%$ of its species not occurring elsewhere (Breitwieser et al., 2012). Gnaphalieae exceed even this figure, with 56 of the 65 species endemic (Schönberger et al., 2020). Four genera are endemic (Ewartiothamnus Anderb., Leucogenes Beauverd, Rachelia J.M.Ward \& Breitw., and Raoulia), and this number is expected to rise when current revision work is published.
A wide range of ecological tolerance is apparent in New Zealand Gnaphalieae, with species found from seashore to mountain top and from bog to semi-desert. They inhabit coastal sands, braided river flood-plains, low tussock grasslands, rocky cliffs, scrub, forest margins, wet banks, arid grasslands, tall tussock grasslands, alpine rock faces, herbfield, fellfield, alpine bogs, snow hollows and mobile screes.

They are morphologically diverse, with forms ranging from tall shrubs (e.g., Ozothamnus R.Br.) through smaller shrubs (whipcord Helichrysum Mill., Figure I), cushion shrubs (pulvinate Raoulia, Figure 2), and one liane (Helichrysum dimorphum Cockayne), to upright, decumbent or prostrate, often woodybased perennial herbs (e.g., Ewartiothamnus) and perennial mat-forming (mat-forming Raoulia, Figure 3) and rosette herbs (e.g., Euchiton Cass.), with or without stolons. Leaves range in length from less than $2 \mathrm{~mm}$ to more than $200 \mathrm{~mm}$ and may be petiolate, sessile, or with the lower part broad but non-photosynthetic and partly sheathing the stem. One species, Helichrysum dimorphum, even has two morphologically and anatomically different leaf types 


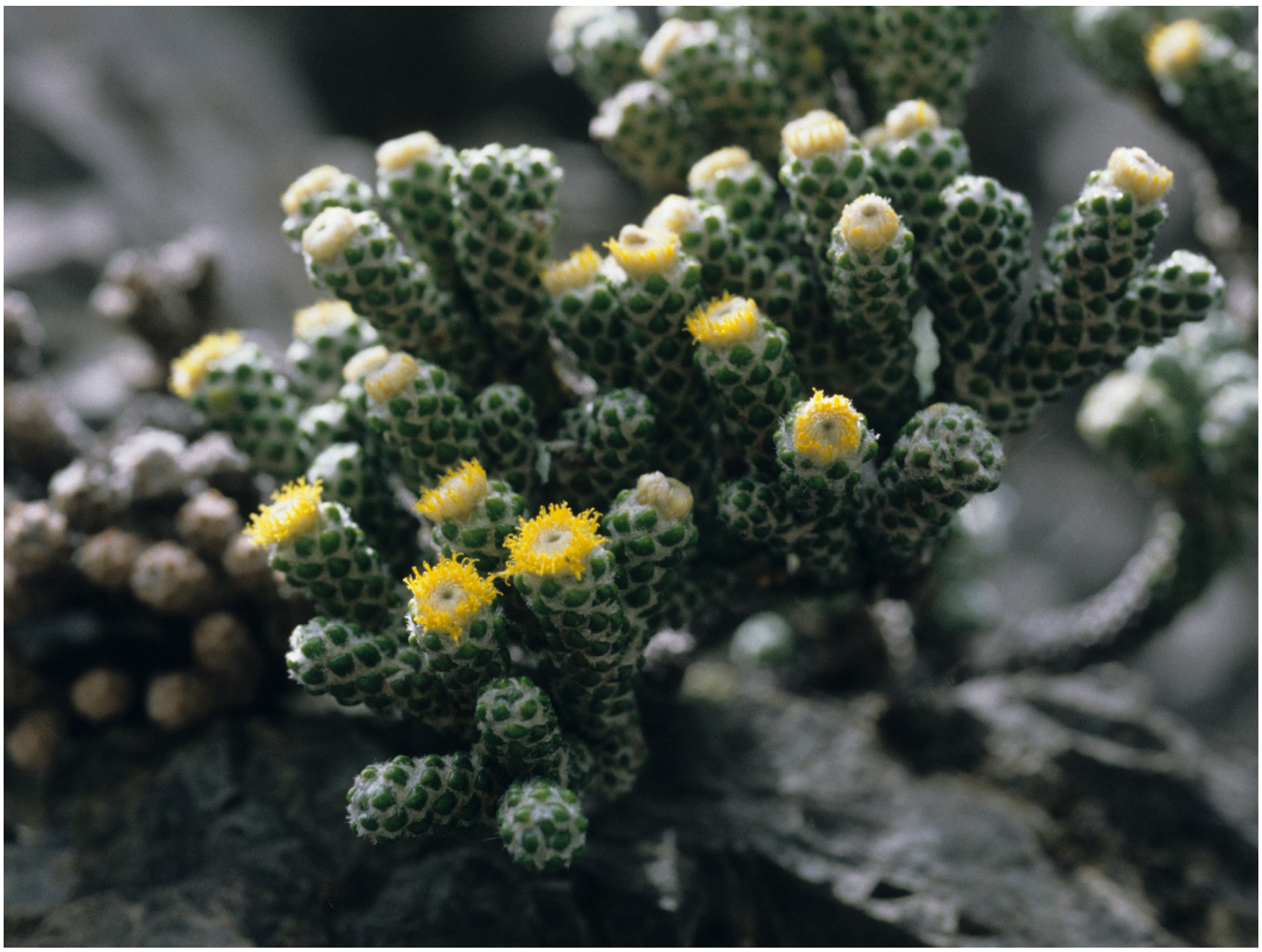

Figure I. The small shrub Helichrysum coralloides (Hook.f.) Benth. \& Hook.f. has an unusual whipcord growth form; Molesworth, South Island. Photo: R.W.Vogt.

alternating in bands up the stem. Capitula are borne in lax to dense panicles (Ewartiothamnus, Figure 4A), in lax [e.g., Anaphalioides (Benth.) Kirp., Figure 4B] to very dense corymbs (Leucogenes, Figure 4C), in loose glomerules [Helichrysum lanceolatum (Buchanan) Kirk] or in densely glomerular secondary heads (Craspedia, Figure 5); frequently they are solitary, and then they may be terminal (e.g., Raoulia, Figure 3C) or lateral and sessile or scapose, or sessile at flowering and scapose at fruiting. Capitula range from homogamous to almost entirely female. Corollas may be white, yellow, red, greenish or colourless, opaque or translucent. Pappus is variable, ranging from a few broad, persistent hairs in a ring to several hundred very fine caducous hairs in several series. Inner involucral bracts may be shorter than the florets or more than twice their length, and range in colour from white through cream to yellow, and from pale translucent brown to almost black. Fruits vary in size, shape, epidermal cell configuration and twin hair type.

Interspecific hybrids are common in New Zealand (Cockayne \& Allan, 1934; Connor, 1985), possibly reflecting the youth of much of the flora and the disturbed nature of the landscape, so the frequency of such hybrids in Gnaphalieae is not particularly surprising. More surprising and noteworthy are the hybrids that occur sporadically in the wild between species in different genera of Gnaphalieae (Allan, 1939, 1961; Ward, 1997).

Asteraceae in general and Gnaphalieae in particular are renowned for being taxonomically difficult. In New Zealand Gnaphalieae taxonomic problems occur at several levels. In Craspedia and Ozothamnus R.Br., for example, generic delimitation is clear but species delimitation is problematic, whereas 


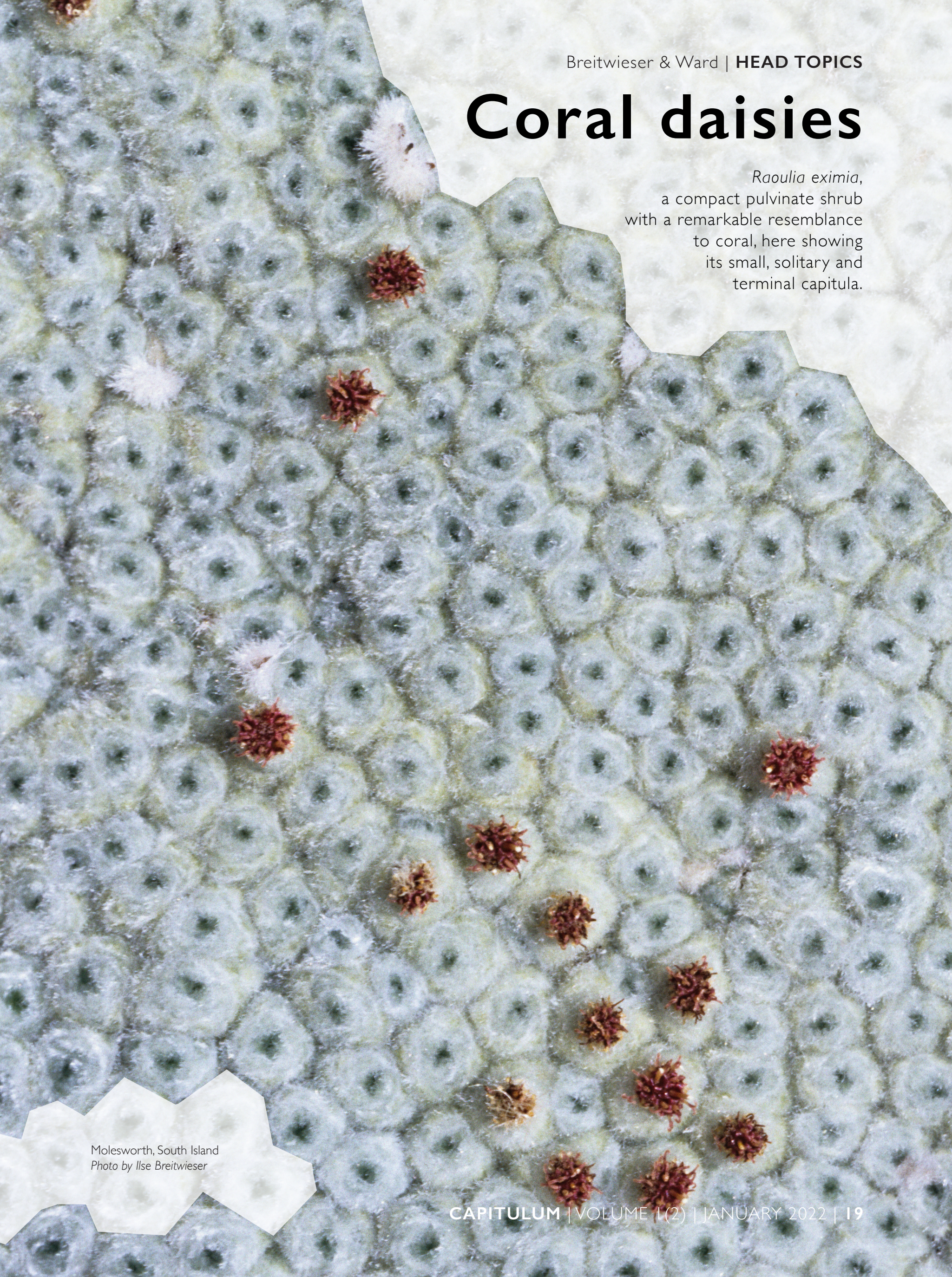



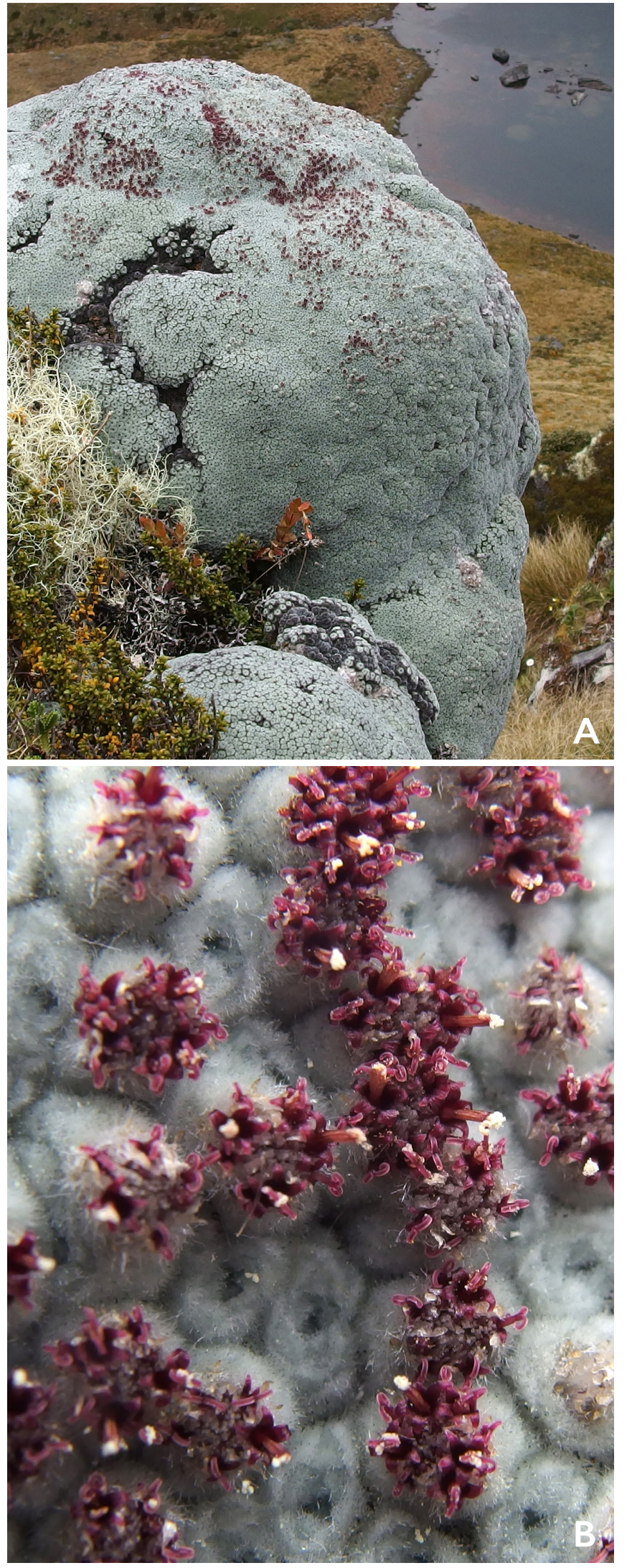

Figure 2. Cushion shrub, Raoulia rubra, Round Lake, Kahurangi National Park, South Island. A. Habit. B. Close up of heads. Photos: K.A. Ford. in Raoulia, species are clear-cut but the genus has defied satisfactory delimitation for over 150 years. A group of genera, including Raoulia, Leucogenes, Anaphalioides, Ewartiothamnus, Rachelia, and those species not yet transferred from Helichrysum, exhibits reticulate character distribution, in which one species may show features characteristic of several different genera. One result of this has been a great deal of horizontal reshuffling, with several species having been assigned at different times to three or four different genera.

\section{SUBTRIBES AND CLADES OF GNAPHALIEAE}

In view of their degree of morphological diversity it is perhaps to be expected that the indigenous New Zealand Gnaphalieae will be taxonomically diverse. This appears to be borne out by the comprehensive classification of Gnaphalieae (Anderberg, I991, 1994), in which they were distributed through four of the five subtribes (the fifth being almost endemic to Africa). However, based on recent advances in our understanding of their phylogenetics and evolution, a revised subtribal classification (Smissen et al., 2020) showed that, with the exception of Pseudognaphalium Kirp., all New Zealand Gnaphalieae belong to the "Australasian clade" within subtribe Gnaphaliinae Dumort. Schmidt-Lebuhn and Bovill's (202I) study of Australian Gnaphalieae, which included only those New Zealand genera also occurring in Australia, placed Craspedia in their "Angianthus clade", Ozothamnus in their "Cassinia clade", and Euchiton Cass. and Argyrotegium J.M.Ward \& Breitw. in their "Euchiton clade", all falling within their "Australian clade".

The remaining six New Zealand genera (Anaphalioides, Ewartiothamnus, Leucogenes, Rachelia, Raoulia, and the species not yet transferred from Helichrysum) comprise the Raoulia alliance (e.g., Smissen et al., 2006). With 42 currently recognized species, the Raoulia alliance is endemic to New Zealand except for two species of Anaphalioides that are endemic to New Guinea. It has also been referred to as the New Zealand endemic clade (e.g. Breitwieser et al., 1999; Smissen et al., 2004). Data from natural and artificial hybridization suggest a close relationship among Anaphalioides, Ewartiothamnus, Leucogenes, Raoulia, 


\section{Vegetable Sheep}

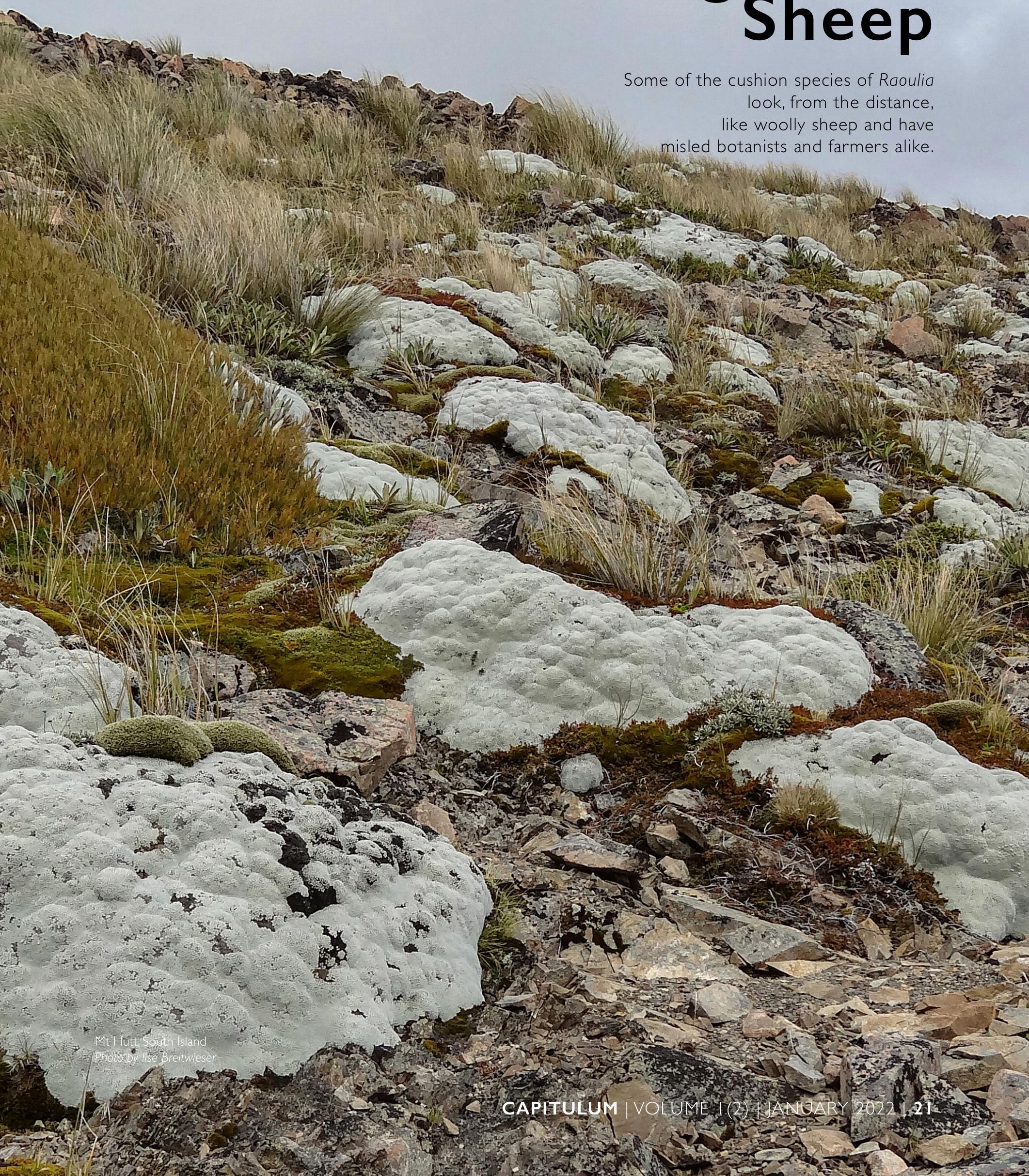




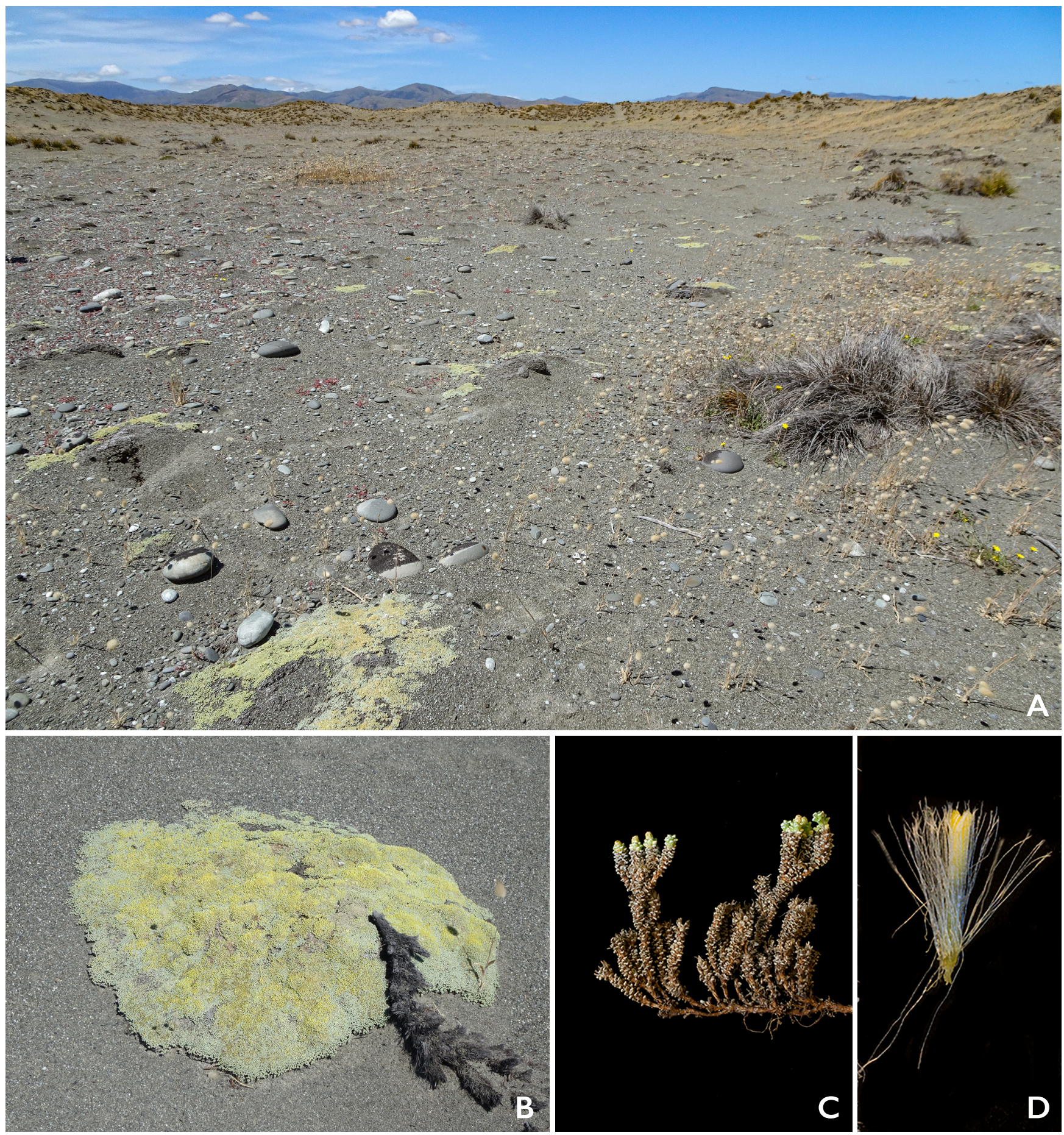

Figure 3. Mat-forming Raoulia australis Hook.f. ex Raoul at Kaitorete Spit, near Christchurch, South Island. A. Habitat. B. Habit. C. Close up of branches, notice long and short shoots. D. Floret. Photos: A-B, R.W.Vogt; C-D, K.A. Ford.

and the species not yet transferred from Helichrysum. This is supported by morphological, anatomical, palynological and molecular data, which also support the inclusion of Rachelia. An ITS sequence analysis of a selection of Australasian Gnaphalieae (Breitwieser et al., 1999) retrieved a strongly supported clade comprising these six genera.

\section{INTERGENERIC HYBRIDS IN THE RAOULIA ALLIANCE}

Crosses between species in different genera are well known in the Raoulia alliance (e.g., Allan, 196I), but only some are well documented. Generally, they occur as isolated individuals, occasionally as very 

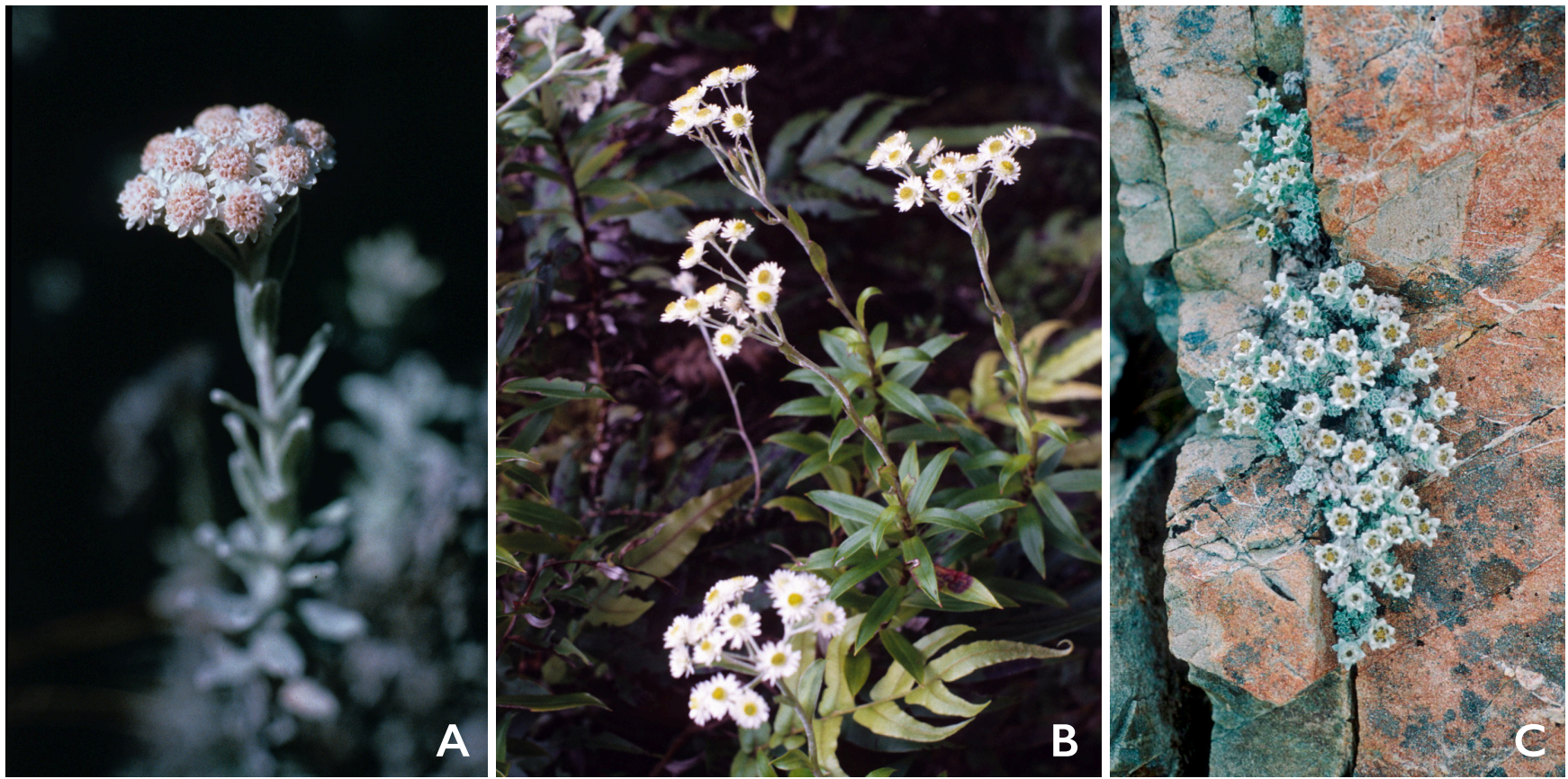

Figure 4. A. Ewartiothamnus sinclairii Anderb. has capitula in lax to dense panicles; it is found only in Molesworth, South Island B. Anaphalioides trinervis (G.Forst.) Anderb. has a lax corymb; Arthur's Pass National Park, South Island. C. Leucogenes grandiceps (Hook.f.) Beauverd has a dense corymb; it grows here in a rock face in Molesworth, South Island. Photos: A-B, R.W.Vogt; C, J.D. Lovis.

small populations, intermediate in form between the putative parents (Figure 6A) and usually in close proximity to one or both (Figure 6B). Within the Raoulia alliance five of the six genera are linked by wild hybrids to at least two of the other genera. The exception is Rachelia, which is monotypic, with a very limited distribution and a specialized alpine habitat on fine scree containing argillite. It does not grow in proximity to any other Gnaphalieae except Raoulia bryoides Hook.f., a cushion shrub that is adapted to a disparate alpine habitat on rock outcrops. Survival of offspring is rare even for these species, so would be very unlikely for hybrids.

Detailed study of hybrids between Anaphalioides bellidioides (G.Forst.) Glenny and Ewartiothamnus sinclairii (Hook.f.) Anderb. (McKenzie et al., 2004, 2008) has demonstrated fertility in the FI generation and successful production of plants from seed of wild and artificial hybrids, with evidence of back-crossing to $A$. bellidioides and possible advanced-generation hybrids. By far the most commonly reported generic combination is between Leucogenes and the pulvinate shrub species of Raoulia subg. Psychrophyton Beauverd (e.g. Allan, 1939, 1961). This may be due in part to the ease of recognizing hybrids between two such morphologically different genera. There is no doubt the hybrids are common in the wild and found in most geographically feasible species combinations. Experimental crosses by McKenzie (200I) generally followed the wild hybrid pattern, except that the autogamous genus Euchiton was crossed successfully with Anaphalioides, Ewartiothamnus, Helichrysum, Leucogenes and Raoulia (but not Ozothamnus or Pseudognaphalium). Attempted crosses between Leucogenes and the similar looking but distantly related Eurasian Leontopodium were unsuccessful.

More recently we used DNA sequencing to confirm intergeneric hybridization between Helichrysum lanceolatum and Anaphalioides bellidioides (Smissen et al., 2007). Using DNA fingerprinting we found some evidence of reduced seed set in hybrids. Two wild back-crosses to $\mathrm{H}$. lanceolatum were identified using AFLP profiles. Subsequent generations have been produced in the glasshouse, and some come close to recovering the morphology of $\mathrm{H}$. lanceolatum (Smissen, unpubl.). However, FI hybrids were far more common than second and later generation hybrids in nature, and introgression between the parental populations was not detected. Glasshousegrown backcrosses to $A$. bellidioides show marked morphological variation, as would be expected in recombinant generations descended from a cross between two morphologically distinct species. 


\section{Everlasting daisies from coasts to mountain tops}

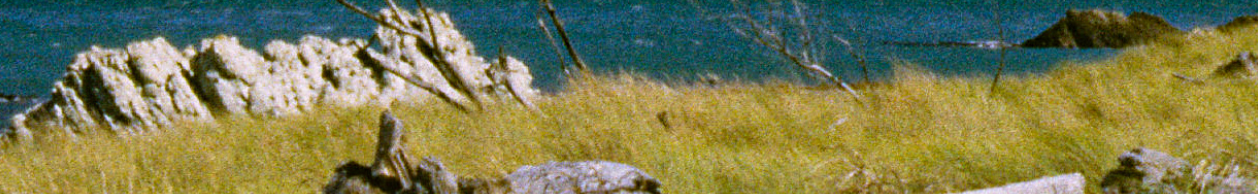

\section{rityon

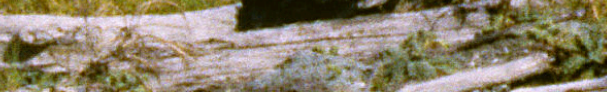

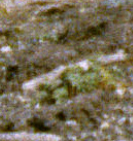

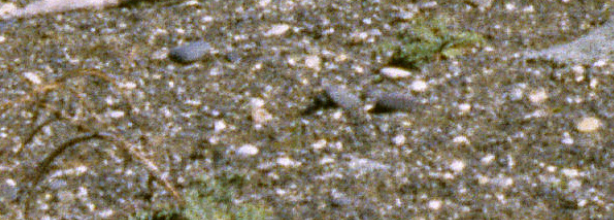

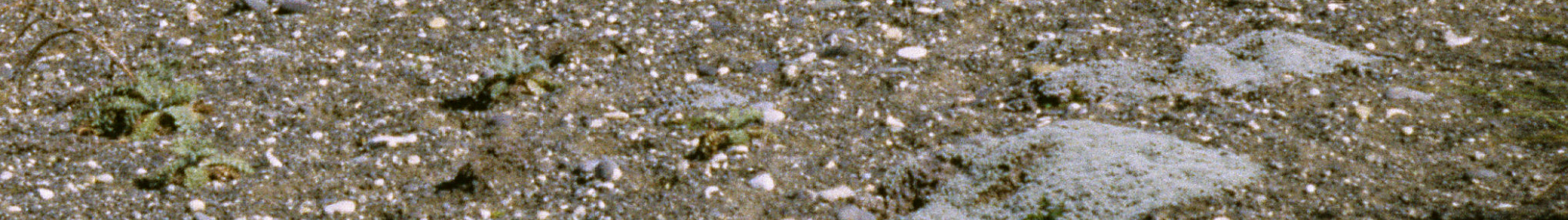

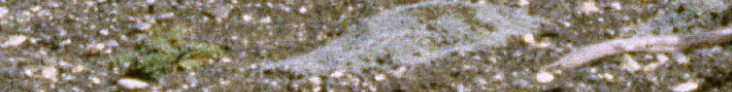

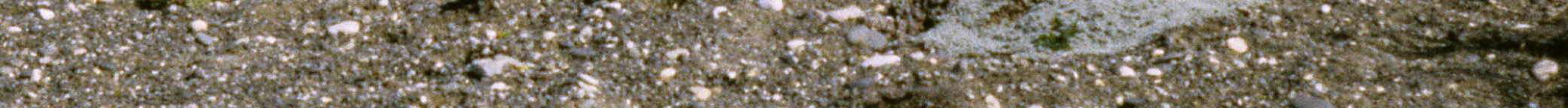

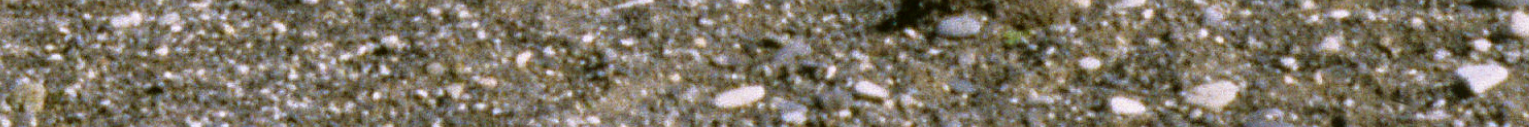

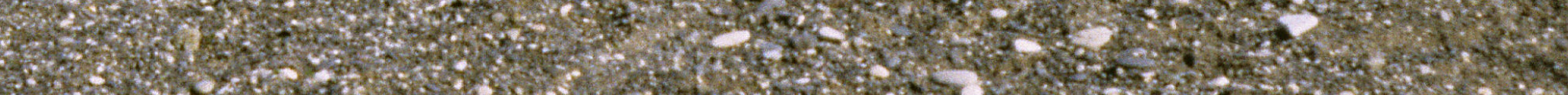

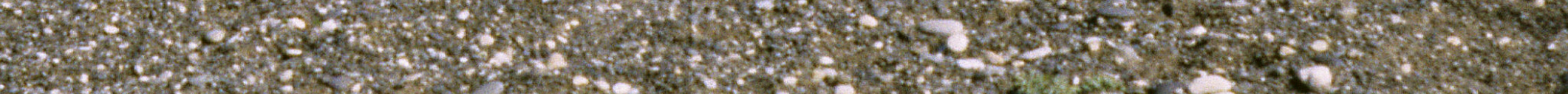

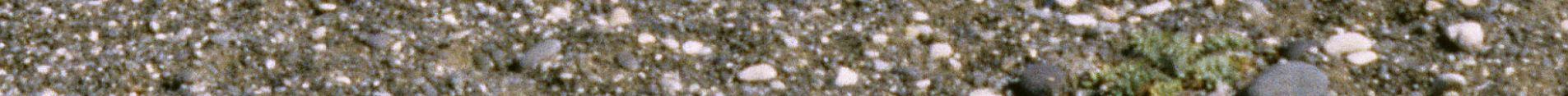

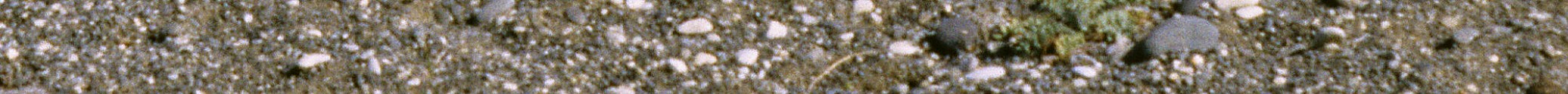

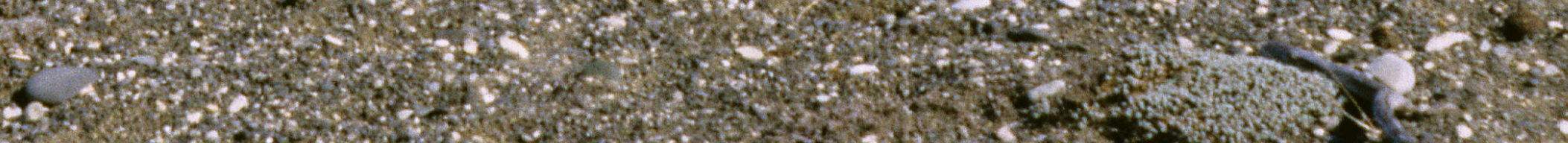

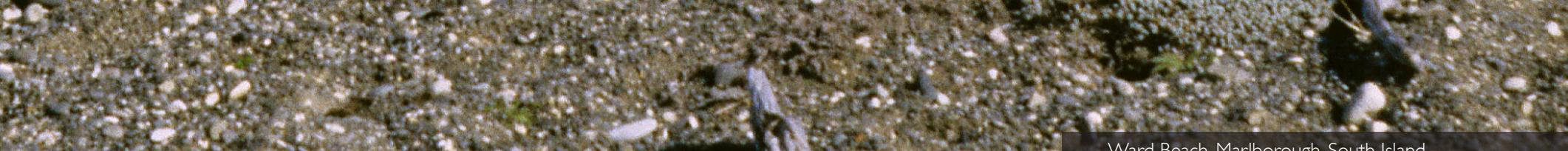

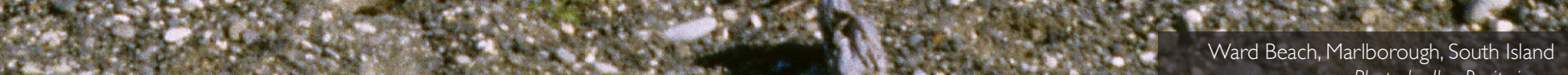

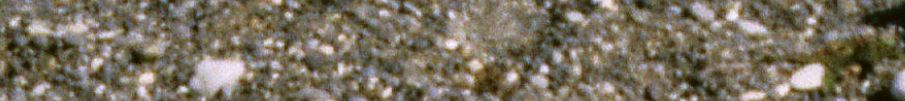

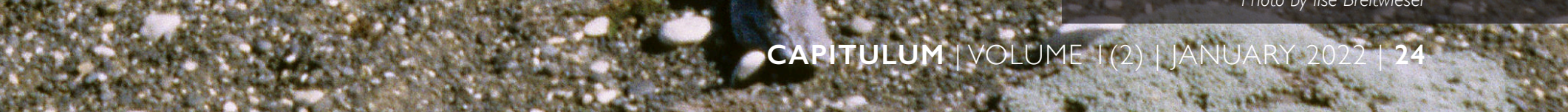

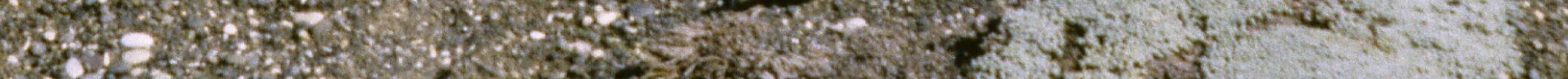



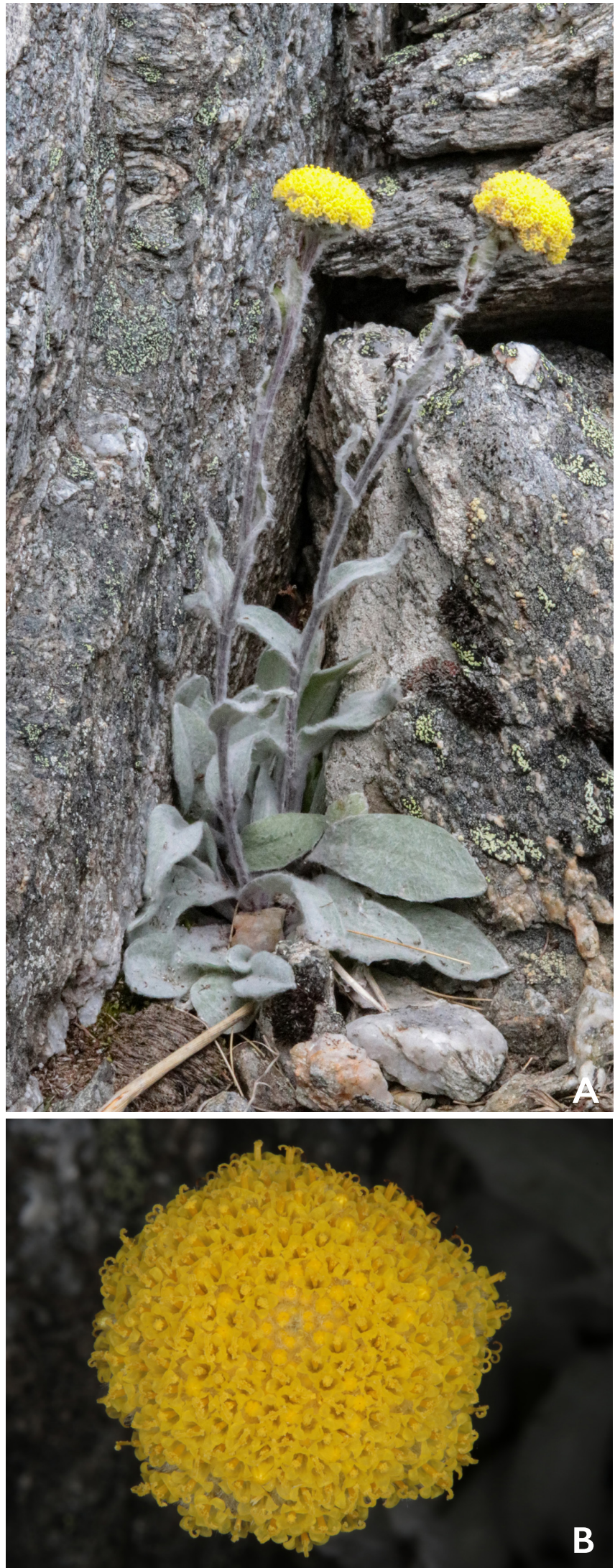

Figure 5. Craspedia lanata (Hook. f.) Allan from the Pisa Range, South Island. A. Habit. B. Close up of densely glomerular secondary head. Photos: R.W.Vogt.
With the help of analyses of nuclear rDNA ITS sequences and plastid trnK intron, we also confirmed that wild intergeneric hybrids occur between Argyrotegium mackayi (Buchanan) J.M.Ward \& Breitw. and Leucogenes leontopodium (Hook.f.) Beauverd (Smissen et al., 20I5). This is the only known instance of wild hybrids between species inside and outside the Raoulia alliance.

\section{MORPHOLOGICAL DIVERSITY AND EVOLUTION OF THE RAOULIA ALLIANCE}

The Raoulia alliance embraces most of the remarkable morphological and ecological variation described above for New Zealand Gnaphalieae, apart from conventional shrubs and rosette herbs. A close relationship among taxa with such diverse morphology may seem unlikely, but some connections between very different forms can be demonstrated. The distinctive condensed corymb of Leucogenes (Figure 7A), with its ring of showy, white-tomentose bracts, found elsewhere in the tribe only in Leontopodium (Pers.) R.Br. ex Cass., is very different from the small, solitary, terminal capitula nested among the uppermost leaves of a pulvinate Raoulia (Figure 7B). Yet a possible linking form can be seen in Rachelia (Figure 7C), in which the capitula are terminal and lateral in the axils of the uppermost leaves. These leaves are large, white-tomentose and very close-set, giving the appearance of a rosette. It would require only minor morphological adjustments to convert this to the inflorescence of a Leucogenes. Alternatively, loss of lateral capitula would result in the solitary, sessile, terminal capitulum of Raoulia. Isolated plants with solitary capitula, but otherwise conforming in all aspects to other plants in the population, have been observed at least twice in Leucogenes (Figure 7C), demonstrating that this transition is developmentally feasible.

The leaves of the whipcord species of Helichrysum (Figure 8 A-B) are scale-like, imbricate, appressed and abaxially glabrous, very different from the spreading, densely tomentose leaves found in other genera. However, the whipcord species are heteroblastic and their juvenile leaves are spreading and densely tomentose (Figure 8C). 

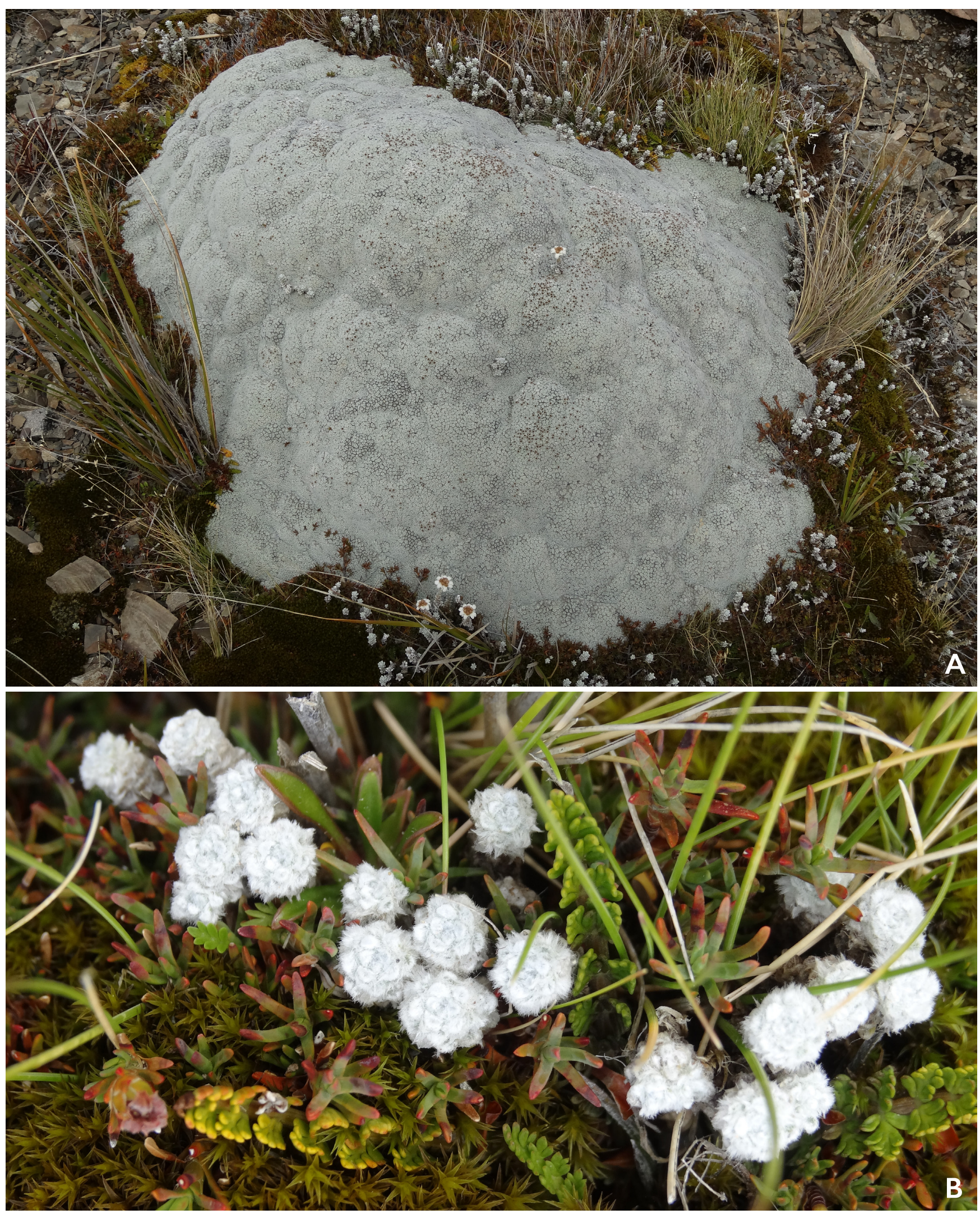

Figure 6. Intergeneric hybrid between Raoulia and Leucogenes at Mt Hutt, South Island. A. Raoulia exima surrounded by Leucogenes grandiceps with one plant of Leucogenes growing in the Raoulia cushion. B. Close up of putative hybrid. Photos: R.W.Vogt. 

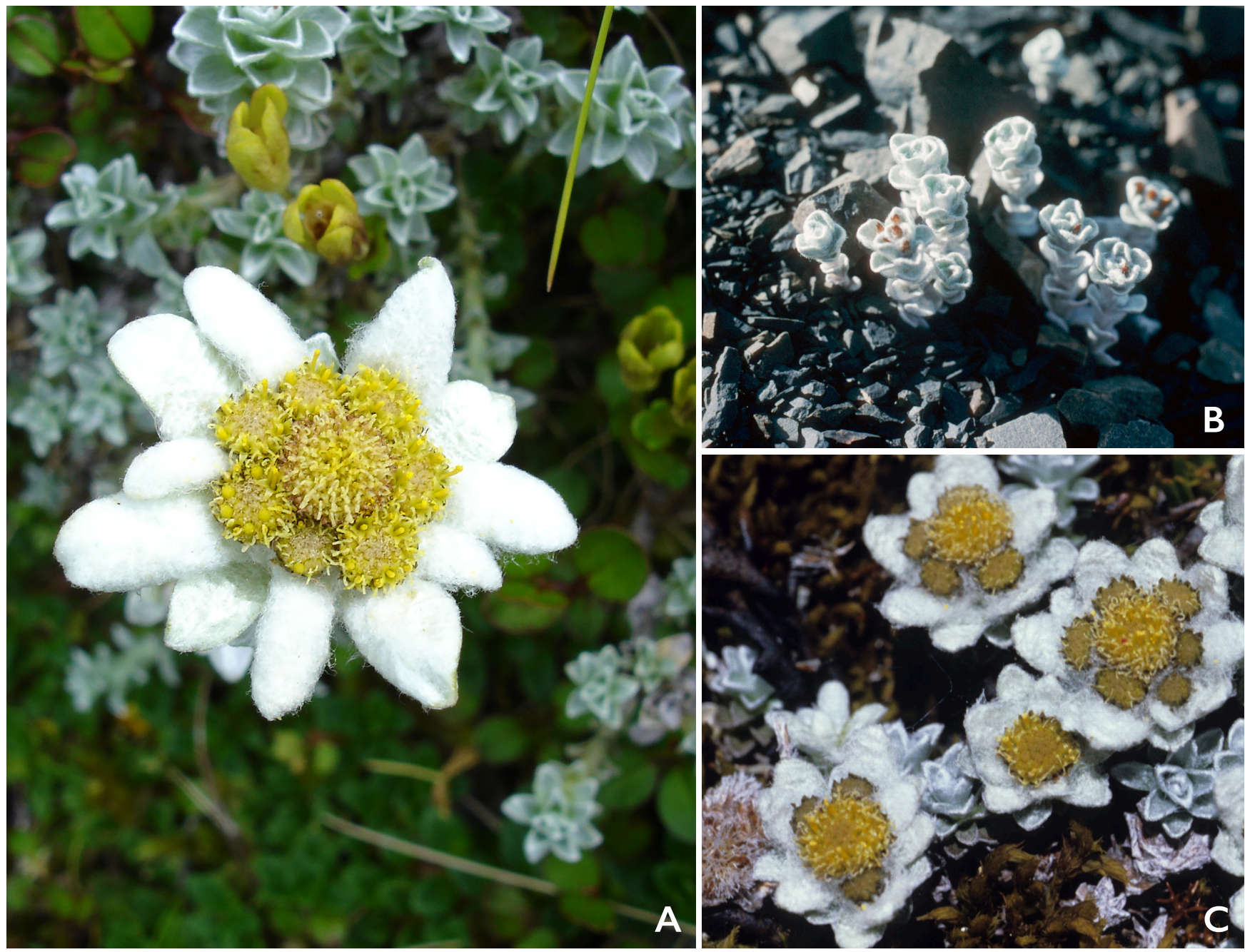

Figure 7. A.The distinctive condensed corymb of Leucogenes. B. Inflorescence of Rachelia, characterized by capitula that are terminal and lateral in the axils of the uppermost leaves. C. Leucogenes showing a solitary capitulum. Photos: A, C: R.W. Vogt; B: I. Breitwieser.

Hybrids are a well-documented source of intermediate and novel characters. We have shown (Smissen et al., 2004) that chloroplast lineages in the Raoulia alliance do not correspond to taxonomic units, with groups suggested by analysis of morphological characters, or with groups indicated by nuclear rDNA ITS sequences. This suggests complex inter-relationships among extant species and past reticulation among diverging populations. Hybridization may have played a significant role in producing the present-day diversity seen in the Raoulia alliance (see Smissen et al., 20II), as well as the reticulate character distribution that makes it so taxonomically intractable. The Raoulia alliance has radiated into a wide array of forms to colonize the myriad new habitats formed by Pliocene/Pleistocene mountain building and glacial/interglacial climate cycles (e.g., Breitwieser et al., 1999; Smissen et al., 2004).

\section{GENERIC PARALLELISMS WITHIN GNAPHALIEAE}

Evidence from hybridization and analyses from sequences of nrDNA spacers, cpDNA and lowcopy nuclear markers support the existence of a morphologically and ecologically diverse mainly New Zealand lineage, the Raoulia alliance (Breitwieser et al., 1999; Smissen et al., 201I), and do not support Anderberg's (199|) classification based on phylogenetic analyses of morphological data and the purported close relationship between Leucogenes and Leontopodium, Anaphalioides and Anaphalis DC., or the cushion-forming species of Raoulia and other Gnaphalieae such as Mniodes (A.Gray) Cuatrec.; nor do they support the pairing of Ewartiothamnus with the Australian genus Ewartia Beauverd. This is surprising, because, with the possible exception of 
Leucogenes and Leontopodium, which have not been monoecious and Mniodes is dioecious. However, the compared in detail, these pairs of genera show much habit (Figure 9) and the unusual leaves of Raoulia more than superficial similarity. Ewartiothamnus and eximia Hook. f. and Mniodes andina (A.Gray) Cautrec. Ewartia (Ward, 1993), as well as Anaphalioides and are almost identical down to the smallest detail. This Anaphalis (Breitwieser \& Ward, 2003), show high leads one to speculate how many cases exist where levels of overall similarity. Raoulia and Mniodes have a true genetic relationship has been obscured by the not been fully compared reproductively, although it is independent acquisition of such remarkably similar known that Raoulia is gynomonoecious to functionally adaptations.
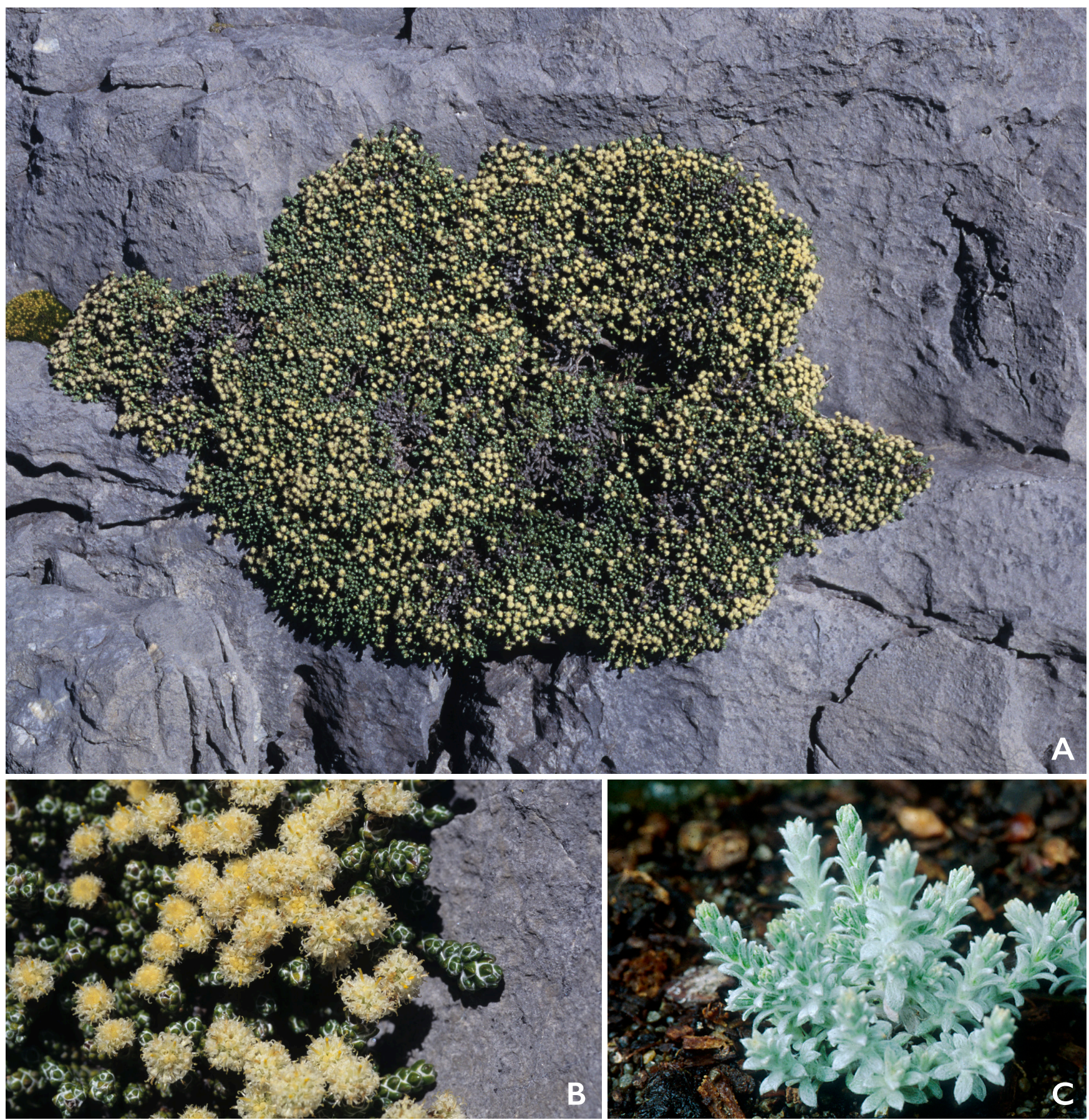

Figure 8. A. Adult form of Helichrysum intermedium G. Simpson has scale-like, imbricate, appressed and abaxially glabrous leaves B. Close up of heads and leaves. C. Juvenile form showing leaves spreading and densely tomentose. Photos: A-B: R.W. Vogt; C: J.M. Ward). 

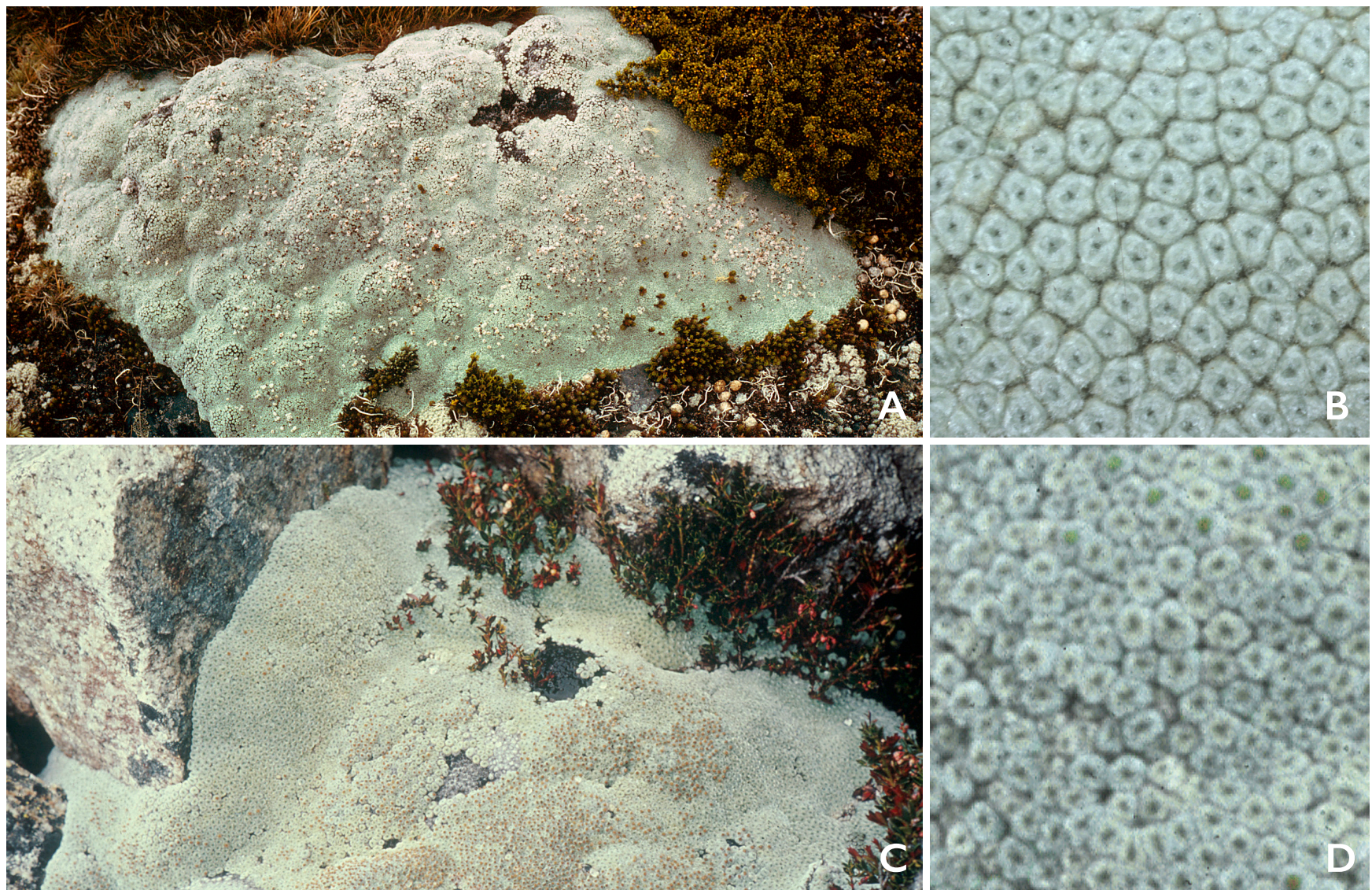

Figure 9. Startling morphological similarities in not closely related taxa. A-B Raoulia eximia (New Zealand). C-D. Mniodes andina (Peru). Photos: A-B: J.M. Ward; C-D: H.Wilson.

\section{ACKNOWLEDGEMENTS}

We would like to thank Rob Smissen and an anonymous reviewer for commenting on the manuscript. IB's contribution to this work was supported by Strategic Science Investment Fund funding for Crown Research Institutes from the New Zealand Ministry for Business, Innovation and Employment.

\section{LITERATURE CITED}

Allan, H.H. 1939. Remarks on X Leucoraoulia. Trans. Roy. Soc. New Zealand 68: 457-46I.

Allan, H.H. 196।. Flora of New Zealand. Vol. I. Wellington, NZ: Government Printer.

Anderberg, A.A. |99|. Taxonomy and phylogeny of the tribe Gnaphalieae (Asteraceae). Opera Bot. 104: I-195.
Anderberg, A.A. 1994. Tribe Gnaphalieae. In: Bremer, K. Asteraceae: Cladistics and Classification. Oregon:Timber Press.

Breitwieser, I., Brownsey, P.J., Garnock-Jones, P.J., Perrie, L.R. \& Wilton, A. 20I2. Phylum Tracheophyta — vascular plants. In Gordon, D. (ed.), New Zealand Inventory of Biodiversity. Vol. 3. Christchurch, NZ: Canterbury University Press, pp. 4I I459

Breitwieser, I., Glenny, D.S., Thorne, A. \& Wagstaff, S.J. 1999. Phylogenetic relationships in Australasian Gnaphalieae (Compositae) inferred from ITS sequences. New Zealand J. Bot. 37: 399-4I2.

Breitwieser, I. \& Ward, J.M. 2003. Phylogenetic relationships and character evolution in New Zealand and selected Australian Gnaphalieae (Compositae) inferred from morphological and anatomical data. Bot. J. Linn. Soc. I4I : I83-203.

Cockayne, L. \& Allan, H.H. 1934. An annotated list of groups of wild hybrids in the New Zealand flora. Ann. Bot. (Oxford) 38: I-55. 
Connor, H.E. 1985. Biosystematics of higher plants in New Zealand 1965-1984. New Zealand J. Bot. 23: 61 3-644.

McKenzie, R.J. 200 I. Intergeneric hybridisation in New Zealand Gnaphalieae (Compositae). PhD thesis, University of Canterbury.

McKenzie, R.J., Ward, J.M. \& Breitwieser, I. 2008. Hybridization beyond the FI generation between the New Zealand endemic everlastings Anaphalioides bellidioides and Ewartia sinclairii (Asteraceae, Gnaphalieae). PI. Syst. Evol. 273: |3-24.

McKenzie, R.J., Ward, J.M., Lovis, J.D. \& Breitwieser, I. 2004. Morphological evidence for natural hybridization in the New Zealand Gnaphalieae (Compositae): Anaphalioides bellidioides $\times$ Ewartia sinclairii. Bot. J. Linn. Soc. 145: 59-75.

Schmidt-Lebuhn, A.N. \& Bovill, J. 2021 . Phylogenetic data reveal four major clades ofAustralian Gnaphalieae (Asteraceae). Taxon 70: 1020-1034.

Schönberger, I., Wilton, A.D., Boardman, K.F., Breitwieser, I., de Lange, P.J., de Pauw, B., Ford, K.A., Gibb, E.S., Glenny, D.S., Greer, P.A., Heenan, P.B., Korver, M.A., Novis, P.M., Prebble, J.M., Redmond, D.N., Smissen, R.D. \& Tawiri, K. 2020. Checklist of the New Zealand Flora - Seed Plants. Lincoln, NZ: Manaaki WhenuaLandcare Research. http://dx.doi.org// 0.26065/s3gg-v336

Smissen, R.D., Bayer, R.J., Bergh, N.G., Breitwieser, I., Freire, S.E., Galbany-Casals, M., Schmidt-Lebuhn, A.N. \& Ward, J.M. 2020. A revised subtribal classification of Gnaphalieae (Asteraceae). Taxon 69: 778-806.
Smissen, R.D., Breitwieser, I. \& Ward, J.M. 2004. Phylogenetic implications of trans-specific chloroplast DNA sequence polymorphism in New Zealand Gnaphalieae (Asteraceae). Pl. Syst. Evol. 249: 37-53.

Smissen, R.D., Breitwieser, I. \& Ward, J.M. 2007. Genetic characterisation of hybridisation between the New Zealand everlastings Helichrysum lanceolatum and Anaphalioides bellidioides (Asteraceae: Gnaphalieae). Bot. J. Linn. Soc. I54: 89_ 98.

Smissen, R.D., Galbany-Casals, M. \& Breitwieser, I. 20 I I. Ancient allopolyploidy in the everlasting daisies (Asteraceae: Gnaphalieae): Complex relationships among extant clades. Taxon 60: 649-662.

Smissen, R.D., Thorsen, M.J., Breitwieser, I. \&Ward, J.M. 2015. DNA sequence analysis confirms the identity of the intergeneric hybrid Argyrotegium mackayi $\times$ Leucogenes leontopodium (Asteraceae: Gnaphalieae). New Zealand J. Bot. 53: $210-215$.

Ward, J.M. 1993. Systematics of New Zealand Inuleae (Compositae-Asteraceae)-2. A numerical phenetic study of Raoulia and allied genera. New Zealand J. Bot. 31: 29-42.

Ward, J.M. 1997. Raoulia and its hybrids. Pp. 40-44 in: Sheppard J. S. (ed.) Southern Alpines '96. Christchurch, NZ: Southern Alpines. 